\title{
Self-regulation of ice flow varies across the ablation area in south-west Greenland
}

\author{
R. S. W. van de Wal ${ }^{1}$, C. J. P. P. Smeets ${ }^{1}$, W. Boot ${ }^{1}$, M. Stoffelen ${ }^{1}$, R. van Kampen ${ }^{1}$, S. H. Doyle ${ }^{2}$, F. Wilhelms ${ }^{3}$, \\ M. R. van den Broeke ${ }^{1}$, C. H. Reijmer ${ }^{1}$, J. Oerlemans ${ }^{1}$, and A. Hubbard ${ }^{2}$ \\ ${ }^{1}$ Institute for Marine and Atmospheric research Utrecht, Utrecht University, the Netherlands \\ ${ }^{2}$ Centre for Glaciology, Department of Geography and Earth Sciences, Aberystwyth University, Aberystwyth, UK \\ ${ }^{3}$ Alfred Wegener Institute, Bremerhaven, Germany
}

Correspondence to: R. S. W. van de Wal (r.s.w.vandewal@uu.nl)

Received: 18 July 2014 - Published in The Cryosphere Discuss.: 1 September 2014

Revised: 5 December 2014 - Accepted: 3 March 2015 - Published: 1 April 2015

\begin{abstract}
The concept of a positive feedback between ice flow and enhanced melt rates in a warmer climate fuelled the debate regarding the temporal and spatial controls on seasonal ice acceleration. Here we combine melt, basal water pressure and ice velocity data. Using 20 years of data covering the whole ablation area, we show that there is not a strong positive correlation between annual ice velocities and melt rates. Annual velocities even slightly decreased with increasing melt. Results also indicate that melt variations are most important for velocity variations in the upper ablation zone up to the equilibrium line altitude. During the extreme melt in 2012, a large velocity response near the equilibrium line was observed, highlighting the possibility of meltwater to have an impact even high on the ice sheet. This may lead to an increase of the annual ice velocity in the region above S9 and requires further monitoring.
\end{abstract}

\section{Introduction}

The Greenland ice sheet is losing mass at an increasing rate (Rignot and Kanagaratnam, 2006; Van den Broeke et al., 2009; Shepherd et al., 2012). Mass loss is caused by increased run-off rates (Van den Broeke et al., 2009; Shepherd et al., 2012; Fettweis et al., 2007) and increased dynamical ice loss (Howat et al., 2007; Joughin et al., 2008; Pritchard et al., 2009; Nick et al., 2013). Therefore, it is of great importance to study the feedback between ice dynamics and surface mass balance (SMB) changes as this may have important implications for the sensitivity of the ice sheet to a warming climate (Parizek and Alley, 2004; Shepherd et al., 2009; Bartholomew et al., 2011). Of particular interest is the notion that sliding velocity may increase due to an increase in melt, bringing more ice to lower regions where melt rates are usually higher, in turn leading to increased melting of ice. On seasonal time scales it has been shown that flow accelerations for land terminating sections of the ice sheet are related to the melt rate, particularly in early summer, suggesting a positive correlation between melt and velocity (Joughin et al., 2008; Zwally et al., 2002; Van de Wal et al., 2008). Later in the ablation season, however, the positive correlation between ice velocity and melt rates breaks down, likely in response to increased subglacial drainage efficiency (Bartholomew et al., 2011; Schoof, 2010; Fitzpatrick et al., 2013). The leading hypothesis assumes that in early summer, water reaching the bed from the surface initially causes increased storage and higher pressures in a distributed drainage system, after which channelization increases drainage capacity (Bartholomaus et al., 2008) and water pressure decreases. Crucial to this discussion is the role of subglacial water pressure variations in modulating ice flow and to what degree the additional seasonal ice displacement is the integrated effect of several transient accelerations (Schoof, 2010; Bartholomew et al., 2012).

Here we will use detailed ice velocity data in combination with accurate melt rates derived from automatic weather stations and year-round borehole water pressure data, which together form a unique data set allowing further interpretation of ice velocity variation in the marginal zone of Greenland. Initially we discuss the velocity data (Sect. 2) and explain how we calculate melt rates (Sect. 3). In Sect. 4 we combine 

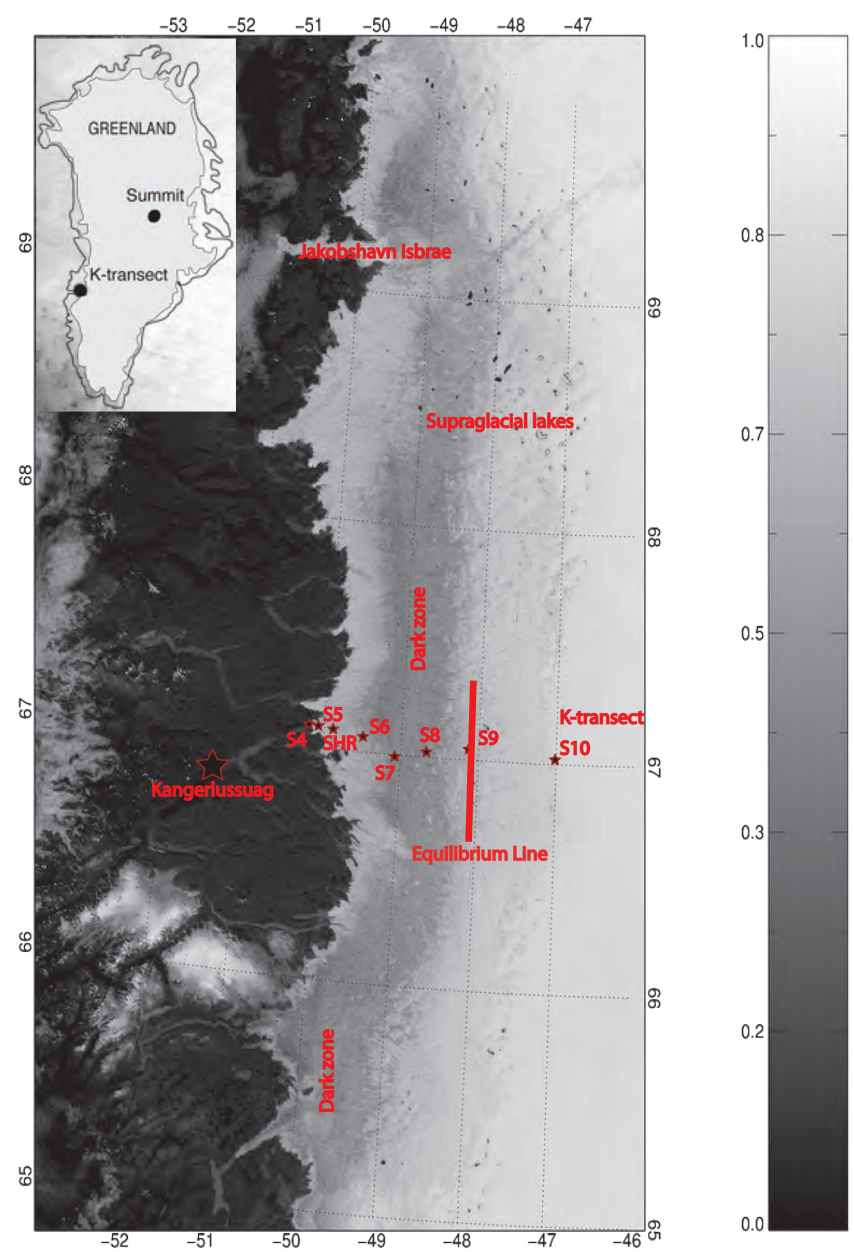

Figure 1. MODIS daily reflectance (band 620-670 nm) indicated by the colour bar on the right-hand side from 21 August 2012, including the sites of the K-transect relative to the ice margin, the dark zone with lower surface albedo and supraglacial lakes. Flow direction is from east to west. The region is characterized by a lack of lakes at the end of the summer season.

the velocity and melt rates with the borehole water pressure data on short time scales. Longer time scales are presented in Sect. 5 and wider implications are discussed in Sect. 6.

\section{Velocities along the K-transect}

Velocity measurements are carried out along a transect in the ablation zone of the western Greenland ice sheet ranging from $340 \mathrm{~m}$ above sea level (a.s.l.) to $1850 \mathrm{~m}$ a.s.l. (Fig. 1). Our 21-year-long velocity record encompasses yearly data based on commercially available single-frequency (L1) receivers prior to 2006 and hourly velocity data over the last 7 years based on L1 GPS instruments developed at IMAU (Institute for Marine and Atmospheric research Utrecht) and optimized for measurements on glacier ice (Den Ouden et al., 2010). Weekly (168-hourly) average positions were cal-

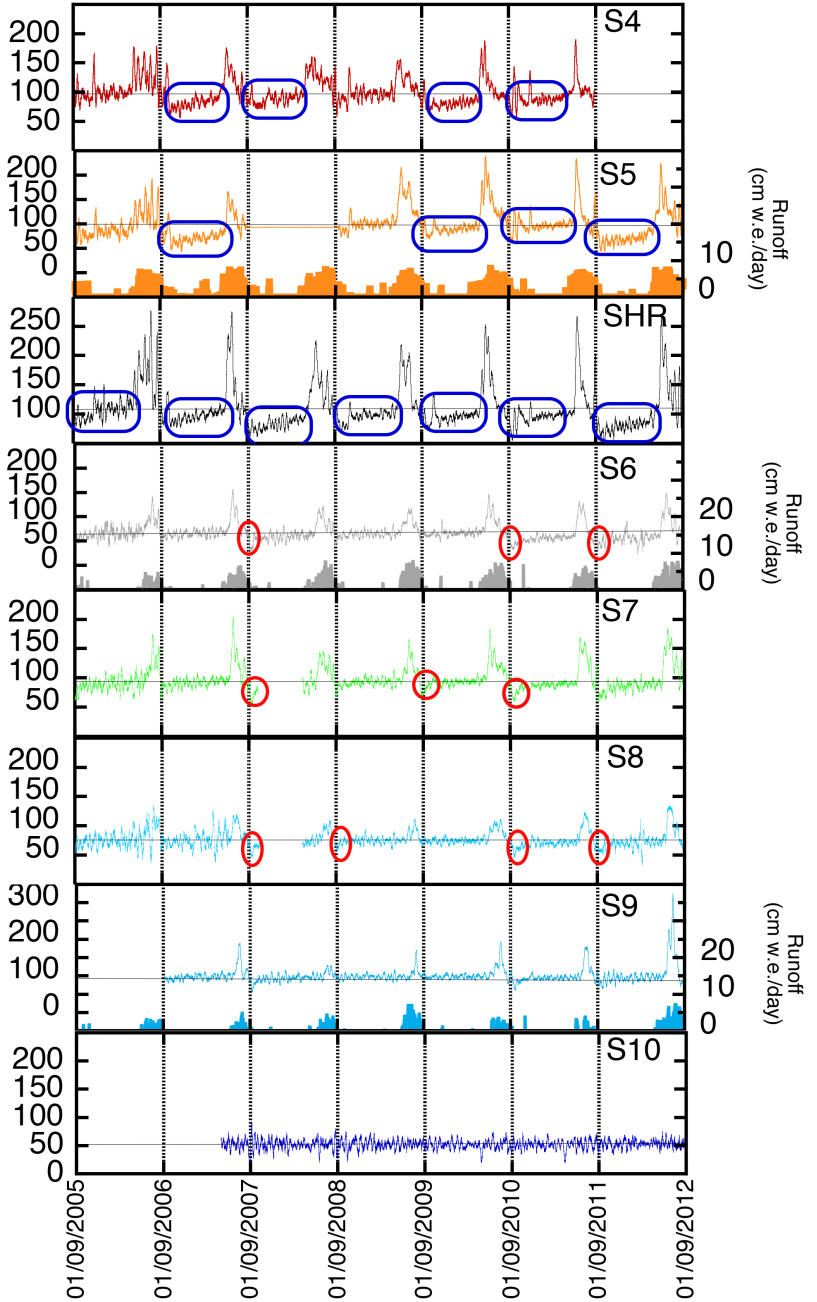

Figure 2. Velocity records from the eight sites on the K-transect with 7 years of data. Data are plotted with respect to their mean values (grey line) and sorted from the ice margin (top) to the accumulation area (bottom), $150 \mathrm{~km}$ from the margin. Note some similar patterns: increase in winter velocity encircled blue and dip in autumn velocity encircled red. For S5, S6 and S9, melt based on AWS data is shown for reference on the right axis. Data in this figure are available in the Supplement.

culated and used to calculate weekly-spaced velocities. Field data from fixed positions in Greenland show a horizontal standard deviation below $0.5 \mathrm{~m}$ for these time intervals. The weekly-averaged velocity data for all eight sites are shown in Fig. 2. Typically, ice velocities increase rapidly at the start of the ablation season, attaining peak values in early summer also called "spring events" and discussed later in more detail. This peak is then followed by weekly variations on a gradually declining velocity pattern in late summer and early autumn (Bartholomew et al., 2010, 2011, 2012; Hoffman et al., 2011). In contrast to the majority of studies that use highpower consumption dual-frequency GPS that shutdown during winter, since 1991 our GPS receivers operated through- 


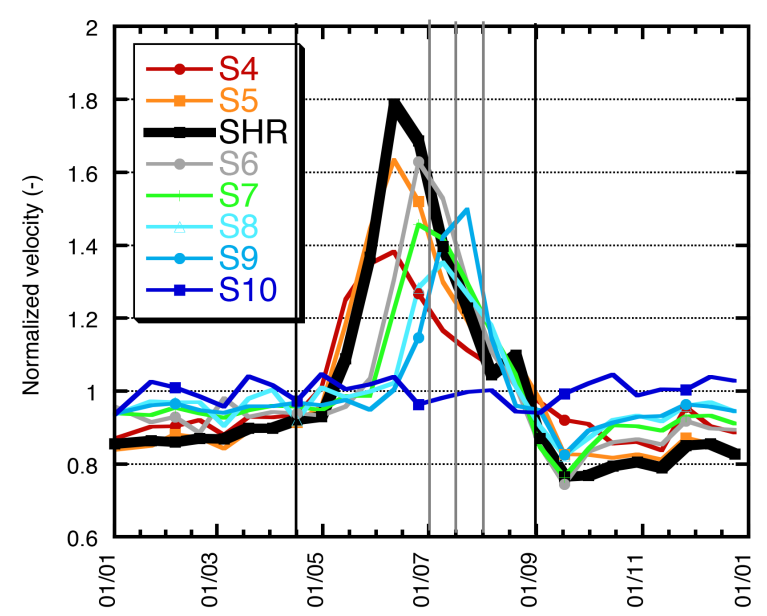

Figure 3. The average seasonal cycle of the velocity at stations S4S10 over the last 7 years. Data are normalized with their mean over the entire period with data available. Note the progressive increase in velocity over winter at SHR. Higher frequency cycles after the summer peak are smoothed by a 2-week-long period filter. The grey lines show the arbitrary range in the separation between early and late summer. Qualitative conclusions are not affected by the arbitrary choice of this date.

out the entire winter. Velocity attains a minimum in late autumn and thereafter gradually increases during winter, with a maximum increase of $13 \%$ at SHR (see Fig. 2) and decreasing to only $6 \%$ for $\mathrm{S} 9$ from early September to mid-April. This seasonal pattern is a consistent feature of the record in the lower ablation region despite a gradual increase in ablation over time. This seasonal cycle in the velocity was also observed for the years 2009 and 2013 by Sole et al. (2013), Tedstone et al. (2013) and Fitzpatrick et al. (2013).

However, near the equilibrium line at site $\mathrm{S} 9$ we observe an exceptionally high peak velocity in 2012 (Fig. 2), the summer with large melt at high elevations (Nghiem et al., 2012). This result contrasts with previous work (Tedstone et al., 2013) that noted no anomalously strong velocity response to the high melt season of 2012 near the close-by site 6 . We observe at S9 that anomalously high melt rates near the equilibrium line yielded a strong local response. The mid-summer response near S9 is larger than the early summer speed-up. The fact that this does not show up in other studies may well be explained by a high degree of spatial variability (Palmer et al., 2011; Joughin et al., 2013)

The seasonal cycle in the velocity averaged over 7 years is shown in Fig. 3. The seasonal amplitude is largest at $7 \mathrm{~km}$ from the margin at SHR, where we observe a large number of moulins and convergence of ice flow into the outlet glacier. Higher in the ablation area, the "spring event" is delayed and of a lower amplitude. After this early summer peak we observe a late summer deceleration. It is somewhat arbitrary at which date to separate early and late summer. In Fig. 3 we used DOY 182, 197 and 212. The deceleration suggest dif-

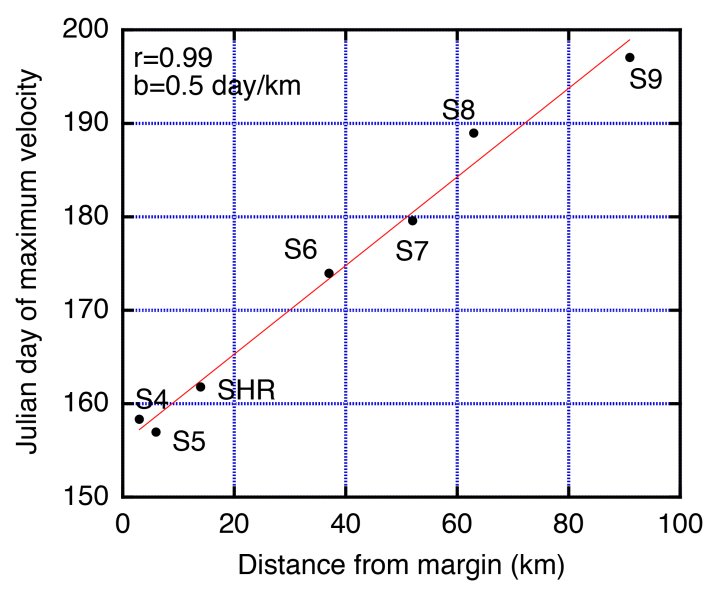

Figure 4. The progression of the early spring event up-glacier. Data are averaged over the period 2005-2012.

ferent responses of the subglacial drainage system and bed properties to surface water inputs (Dow et al., 2013), depending on the location with respect to the equilibrium line. The delay of the spring event higher on the ice sheet is illustrated in Fig. 4 and confirms the idea that the spring event is related to the onset of the melt season; this idea goes back to the earliest measurements of this type in Alpine environments (Iken et al., 1983). In order to discuss this in more detail we use data from automatic weather stations to estimate the melt rates.

\section{Surface mass balance calculations}

We calculate hourly melt energy based on three weather stations at S5, S6 and S9 (Van den Broeke et al., 2008). To calculate the available melt energy we add the net radiative flux to the sensible and latent heat flux. The net radiation is calculated from the measured components of radiation. The turbulent fluxes are derived using a bulk aerodynamic method. The latter method uses gradients of wind speed, temperature and humidity between a single measurement level $(5 \mathrm{~m})$ and the surface. For a melting ice surface these surface values are fixed at $0 \mathrm{~m} \mathrm{~s}^{-1}, 0^{\circ} \mathrm{C}$ and $4.8 \mathrm{~g} \mathrm{~m}^{-3}$ respectively. The bulk aerodynamic method assumes the height for these values to be equal to the aerodynamic and scalar roughness lengths above the underlying ice surface, which we estimated following the results from Smeets and Van den Broeke (2008a, b). For location SHR and S5, both consisting of a rough hummocky ice surface, we used a representative constant aerodynamic roughness length of 0.01 and $0.025 \mathrm{~m}$ respectively for the whole ablation season. Scalar roughness lengths were calculated using a surface renewal model (Andreas, 1987) modified for application over rough ice surfaces as suggested by Smeets and Van den Broeke (2008b). The effects of atmospheric stability are corrected for using an iterative method. Eventually we convert melt energy to melt water production 
by assuming an ice density of $900 \mathrm{~kg} \mathrm{~m}^{-3}$ and a latent heat of fusion of $335 \mathrm{~kJ} \mathrm{~kg}^{-1}$. Estimated standard deviations for errors in the daily totals of turbulent and radiation fluxes are about 6 and $2 \%$. As radiation usually dominates melt rates, daily mean errors are estimated to be $5 \%$. As the region studied is an ablation zone with low accumulation rates and the period of interest is mainly summer, we do not distinguish between melt rates and run-off. Refreezing is only a small fraction in this area.

\section{Velocities, melt and water pressures on short time scales}

Year-round basal water pressure measurements are obtained from a pair of boreholes near SHR (Smeets et al., 2012). The two boreholes, located $5 \mathrm{~m}$ apart, yielded almost identical records over the first year of measurements, and data indicate a connection to the subglacial system. Further proof of an immediate connection to the active subglacial system was the sudden drop in water level when drilling the first bore hole. Previous observations of water pressure variations in combination with velocity measurements in Alpine glacier environments (e.g. Iken and Bindschadler, 1986) and in Jakobshavn Isbræ (Iken et al., 1993) revealed insight into the relation between sliding velocity and water pressure. For Greenland, first data by Meierbachtol et al. (2013) indicated a very variable pattern in time and space in the ablation zone over summer. Here, we provide the first year-round record of water pressure variations beneath the Greenland ice sheet, which in combination with detailed ablation information and GPS data help to constrain hypotheses about the links between surface meltwater production and dynamic response.

Results presented in Fig. 5 show that at the onset of the ablation season at the beginning of July, there is a short-lived peak in subglacial water pressure above the slowly increasing late-winter values, associated with a sharp rise in ice velocity. This is interpreted as the result of a strong imbalance between melt water supply and drainage capacity, leading to a water pressure higher than the overburden pressure and reduction of bed traction, called the spring event (Bartholomew et al., 2011; Fitzpatrick et al., 2013; Sundal et al., 2011; Cowton et al., 2013; Iken et al., 1983). Following the spring event, the simultaneous drop in ice velocity and pressure clearly indicates the transition of the drainage system into an efficient network of channels. The rapid increase of melt water supply during early summer enlarges conduits due to wall melting that develop into efficient channels. The increasing transport capacity leads to lowering of the pressure in the hydraulic system in the vicinity of the channels (Schoof, 2010). This is in agreement with our observations in Fig. 5 and confirms that our pressure probes are connected to an active part of the hydrological system in the vicinity of a channel.

During the period dominated by channels, there is a clear relation between melt, water pressure and velocities on daily

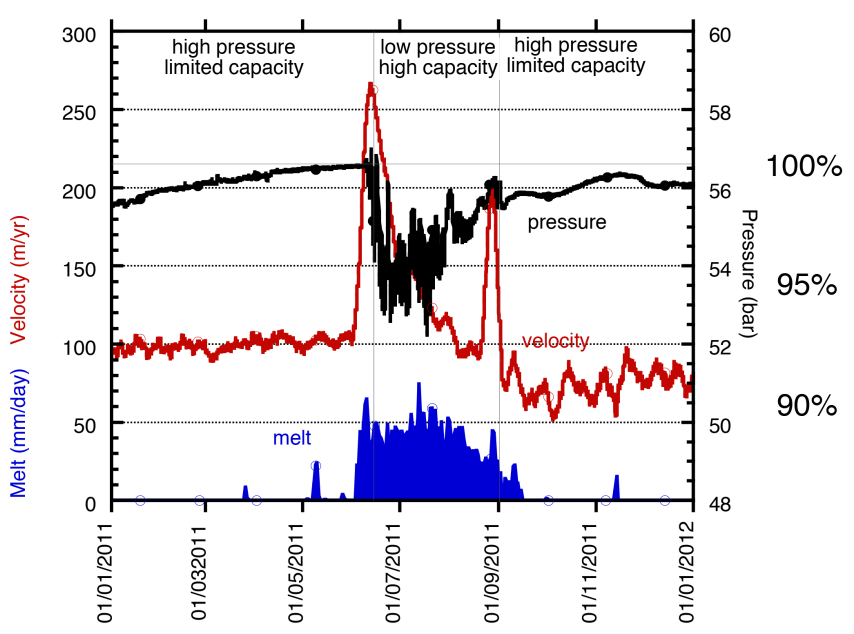

Figure 5. Seasonal cycle of water pressure, melt and velocity at SHR starting in January 2011. Note how the onset of significant melt leads to high magnitude acceleration and a short period of water pressure in excess of the overburden pressure (horizontal grey line), which implies floatation. Later, the ablation season variability in the water pressure remains visible but the amplitude is diminished. During the ablation season the hydraulic system of channels develops (phase 1 in the figure) and closes once the melt decreases (phase 3). Note that even in autumn and early winter, single melt events affect water pressure and ice velocity. Ablation rates are linearly from 0 to $8.5 \mathrm{~cm}$ w.e. per day. The percentages indicate the pressure scaled by the overburden pressure.

time scales. To highlight this we selected a 3-week period in July 2010 to study the diurnal cycle in detail (Fig. 6). Water pressure and ice velocity are direct measurements, and melt is calculated from weather station data. All data are from the site SHR. Melt rates attain their maximum during mid-afternoon, coinciding with the temperature maximum and just after the maximum in shortwave radiation. This is followed by a maximum in water pressure $2 \mathrm{~h}$ later as the hydraulic system is not capable of handling the maximum melt peak immediately. Coinciding with the maximum water pressure, we observe that the velocity increases to $50 \%$ above the mean for a short period, subsequently followed by more or less constant values overnight until 10 a.m. (Local Time), where after the increase in water pressure and melt leads to a decrease in friction and an acceleration of the ice velocity. Water pressure keeps decreasing overnight as the water input decreases due to melt but picks up a little later than the onset of the melt in the early morning again once the system is filled again. Hence the capacity of the subglacial drainage system continuously adapts to time-varying water inputs (Schoof, 2010; Bartholomew et al., 2012). Later in the season, when melt ceases, the channels close and the clear relation between melt, water pressure and velocity becomes less distinct as the system returns to an inefficient, distributed system in autumn (Schoof, 2010). 


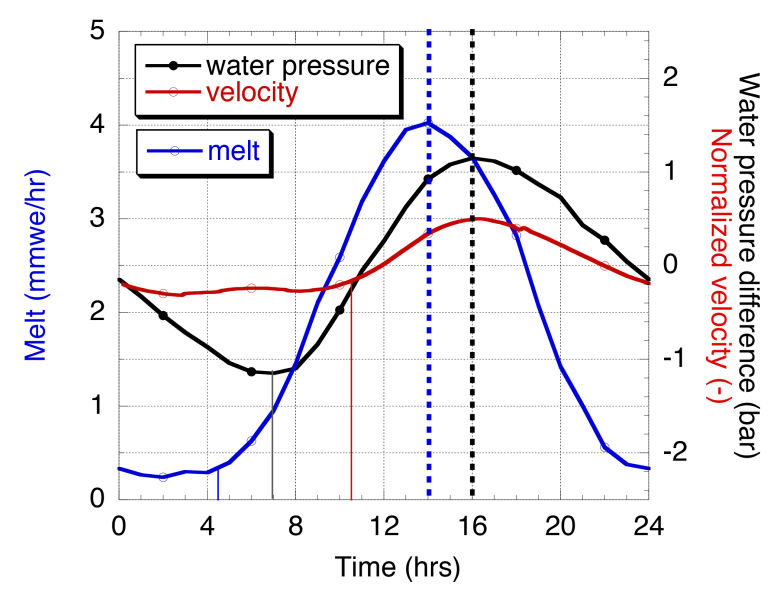

Figure 6. The average daily cycle for a period of 3 weeks in July 2010. Melt production peaks in the afternoon and ceases overnight. Vertical dashed lines indicate peak values and vertical solid lines indicate timing of acceleration in the morning.

Around mid-summer, melt water production at SHR is at its maximum and water pressure at its minimum indicating the most efficient drainage system (Schoof, 2010) (Fig. 5). During the second half of summer, melt water production slowly decreases, and pressure starts to increase while velocity continues to decrease, albeit at a more gradual rate. In the autumn, water storage gradually decreases due to reduced surface melt rates, while drainage efficiency remains relatively high. This appears to result in high bed traction and minimum ice velocities. It is important to note that absolute water pressure as measured at SHR does not drive velocity variations, as seen by the difference between velocities before and after the melt season when water pressures are similar (Fig. 5). Possibly other temporal sources of water storage impact the relation between water pressure and velocity, but the strong transient drainage capacity of the system also contributes to this.

In autumn when surface melt water production stops, daily pressure variations end and the subglacial drainage system quickly reverts to a low-capacity, inefficient state. Remaining water in the system (e.g. basal melt and/or water supplied from reservoirs farther up-glacier) is increasingly pressurized, with subglacial effective pressures decreasing asymptotically over the winter season. In tandem, ice velocities slowly increase, suggesting a decrease in bed traction (Fig. 3).

At S4, S5, SHR and S6, the ice velocity records show a similar annual pattern as that described for SHR, suggesting a comparable evolution of the hydraulic system. At S7, S8 and S9 a velocity peak is also present in all years, but the subsequent slowdown is of much shorter duration and winter velocities are more constant. We interpret this difference as a response to varying duration of surface water inputs. In the lower ablation zone, high melt rates are sustained for several weeks, and subglacial discharges are high enough to maintain a high-capacity, low-pressure state throughout the ablation season. Consequently, the summer and early winter are characterized by low ice velocities that are sustained for long enough to offset the short-lived spring event peak. In contrast, at higher elevations the melt season is much shorter, efficient drainage systems have little time to develop, and summer velocity slowdowns are of shorter duration.

At S10 there is neither a seasonal signal nor an increase in annual velocities over time within the accuracy of our instruments. Recently (Doyle et al., 2014) it was shown, based on dual-frequency GPS measurements, that at S10 in summer 2012 velocities are also slightly higher by $8 \%$ and annual velocities increased by $2 \%$ from 2009 to 2012 .

\section{Velocities and melt rates on seasonal to decadal time scales}

An alternative approach to investigating the links between climate and ice dynamical response, circumventing the details of the underlying processes, is to consider the statistical relation between melt rates and velocities during the season. A limitation is that surface mass balance data, based on stake readings, are available only with yearly intervals on all the stations, whereas velocity data are available every hour. In order to circumvent these limitations we consider the annual velocity at the different sites over the period $y=x, \mathrm{DOY}=116$ to $y=x+1, \mathrm{DOY}=116$, where $y$ is the year, $x$ runs from 2005 to 2011 and DOY is the day number. Day 116 is chosen such that it precedes the start of the melt season in all years at all stations. We hypothesize that the velocity increase is caused by the magnitude of the surface mass balance (not the other way around), so we use the period $y=x-1$, DOY $=243$ to $y=x, \mathrm{DOY}=243$ for the surface mass balance. This yields the annual velocity response to the surface mass balance perturbation over the preceding period. We partition the season into winter and summer. The summer season is defined by the melt considerations and runs from DOY 116 to DOY 243. We additionally divide summer in two periods - early summer velocity and late summer velocity - because we observe a different response during different times of the year. It may be noted that the results do not critically depend on where the split between the early and late summer is chosen.

By using these subdivisions within seasons, we find for each station separately a negative correlation $(r>0.5, n=7)$ between melt rate and late-summer velocity, expressing that more melt (a more negative surface mass balance or higher melt rate) leads to lower velocities in late summer.

However, the statistical correlations neither occur during all parts of the season nor are for all stations identical. It is only for the upper ablation that we do find a positive correlation between early summer velocities and melt rates. This is shown in Fig. 7, which shows a stacked result of the four up- 


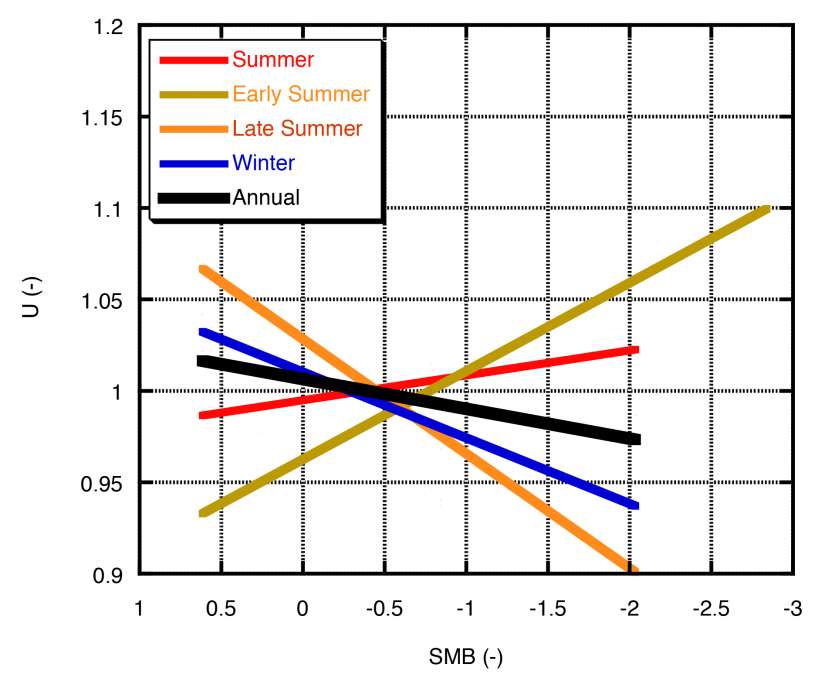

Figure 7. Relation between velocity and surface mass balance (SMB) for different seasons averaged over the upper ablation area (S6-S9). SMB data of different years are normalized with the mean over the period 1990-2010 and divided by the standard deviation. Velocity data are normalized with their mean over the corresponding season and then averaged. Data for velocity and mass balance refer to the period 2005-2012. All fits are statistically significant (minimum $r=0.79$; maximum $r=0.96, n=$ minimum 5 years; $n=$ maximum 7 years).

per ablation area stations (S6, S7, S8, S9). It shows that early summer velocities are higher when there is more melt. For the lower region this is not statistically significant. The net effect over summer in this region is the combined effect of early and late summer, where the early summer dominates. In addition, we observe that in the upper ablation area there is a negative correlation between melt rate and velocities over winter, i.e. more melt leads to lower winter velocities in the upper ablation area. The net effect of the opposing trends for winter and summer in the upper ablation area is dominated by the longer winter season, suggesting that more melt leads to lower velocities in the upper ablation region. For the lower region this is again not statistically significant. Figure 7 indicates that annual velocities typically decrease by a few percent when the melt increases by 2 standard deviations. Hence we conclude that there are annual variations in the velocity with a coherent pattern, but the changes are small and more melt leads to lower velocities in the upper ablation region.

Recently, Sole et al. (2013) showed that in the lower ablation area for a single year with high melt and strong early summer speed-up, annual velocities are offset by reduced winter velocities. Here we demonstrate that this is a general feature at least in this area over the last 7 years (Fig. 7). Our data from the upper ablation area data show that years with higher-than-average summer melt and ice velocities (e.g. 2007, 2010 and 2012) are followed by winters with below average ice velocities. In the lower ablation area, however, the annual response to melt rates is not significantly corre- lated to melt rate, as also noted by Sole et al. (2013). Only the late summer decrease is significantly correlated to melt rates, as has been reported earlier (Colgan et al., 2011, 2012; Sundal et al., 2011). Hence, our results confirm the hypothesis that the melt-induced acceleration is offset by the subsequent slowdown caused by efficient drainage and higher bed traction, hereby providing the solid empirical evidence for earlier postulations that this might be the case (e.g. Truffer et al., 2005; van de Wal et al., 2008; Parizek, 2010).

Our observations also agree with recent tracer studies (Chandler et al., 2013) suggesting the development of an efficient subglacial drainage system over the season of up to $40 \mathrm{~km}$ from the margin. Superimposed on the gradual decrease of ice velocity during summer, stronger ablation events or lake drainage events (Hoffmann et al., 2011; Das et al., 2008; Doyle et al., 2014) overpressure the system and lead to high-amplitude but short-lived flow accelerations. Velocity changes in this period are driven by the variability in the melt water input into the system rather than by the absolute melt water volume (Schoof, 2010; Bartholomew et al., 2012). The positive correlation between ice velocity and melt rate in the early part of the season dominates over the entire summer in the higher parts of the ablation region (Fig. 7). At lower elevations (S4, S5, SHR), however, we find no statistically significant correlation between melt intensity and summer velocity between 2005 and 2012 .

\section{Velocity changes near the equilibrium line altitude}

The overarching question arises: will ice flow increase in a future warmer climate? The compensating relation between early summer speed-up and a decrease in ice velocities in the following winter suggests that the coupling between ice flow and the subglacial hydraulic system is complex and self-regulated. Long-term correlations between ice velocity and melt rates are limited. For the last 21 years there is no evidence for a strong positive correlation between annual melt rate and annual ice velocities as shown in Fig. 8. It is likely, though, that in warmer years the basal footprint of the ice sheet susceptible to melt water input and basal motion expands as the ablation zone expands to higher elevations concomitant to the inland expansion of supraglacial lakes (Howat et al., 2013; Fitzpatrick et al., 2013). Along the Ktransect the equilibrium line is often close to $\mathrm{S} 9$ but can not precisely be determined from year to year as we have no information on refreezing. We do, however, know that 2012 is an extreme year as the equilibrium line altitude is above our highest site (S10 at $1850 \mathrm{~m}$ a.s.l.). When we estimate the equilibrium line altitude from a linear extrapolation of the mass balance data at S9 and S10, we arrive at an elevation above the ice divide, which excludes the presence of an ice sheet at this latitude if it were maintained for a long time period. Despite the obvious large uncertainty it is safe to conclude that in this area the equilibrium line is exceptionally 


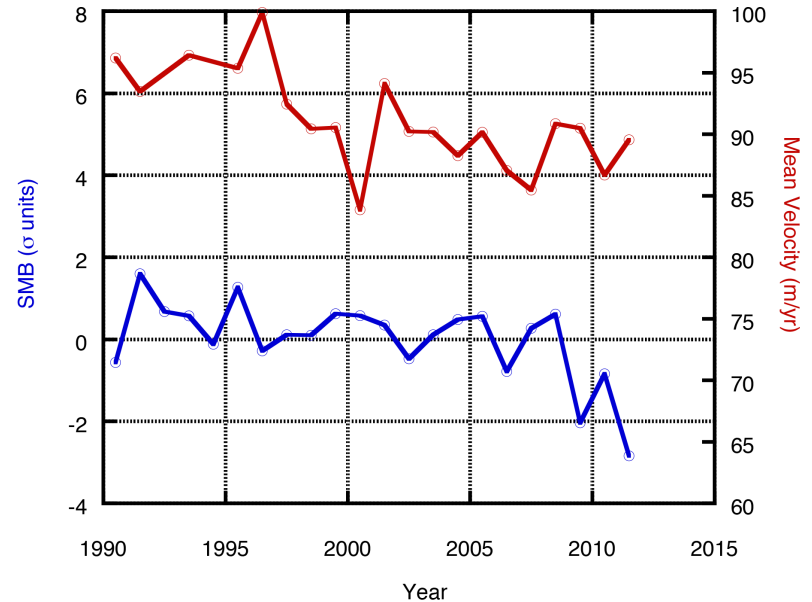

Figure 8. Decadal trends in SMB and velocity from 1990 to 2012. Data (Van de Wal et al., 2012) suggest a gradual decrease in SMB with superimposed large interannual variability and a decrease in velocity over time. Data for SMB and velocity are weighted mean values over the entire ablation area (19), where the individual sites are weighted proportionally to the area they cover along the transect.

high in 2012 as the SMB has never been so negative at S10 over the last 20 years.

At the same time we observe that the annual velocity increases by a factor of 2, going from S10 to S9. No detailed vertical distribution of the horizontal velocity is available; hence we roughly estimate sliding to be responsible for half the velocity in this area, as thickness and slope are not known accurately enough to conclude anything else. The crucial point is that Fig. 2 suggests that at site S9, located near the equilibrium line ( $1500 \mathrm{~m}$ a.s.l.), the magnitude of the summer acceleration has increased in recent years (Fig. 2). This has to be explained as a direct response to local melt water input and not longitudinal stress coupling as suggested for some regions (Price et al., 2008), because seasonal velocity variations on the lower parts are more or less similar to previous years. Additionally, the time delay of peak velocities along the transect is in concert with up-glacier expansion of the ablation zone (Fig. 4), indicating that local melt water production is the primary forcing.

Nevertheless, the transition between cold-based and warm-based conditions may occur rapidly following penetration of surface water to the bed due to latent heat release during refreezing, a process sometimes called cryo-hydrologic warming (Philips et al., 2010). As a consequence, ice speedup by sliding may occur rapidly in response to increased surface melting at high elevations. During the exceptional melt extent of 2012, when melt occurred over $98.6 \%$ of the ice sheets surface area (Nghiem et al., 2012) and the equilibrium line altitude attained an unprecedented elevation, S9 accelerated to over double its previous velocity maximum in 2010 (Fig. 2). This remarkably fast response to additional water input suggests that even in a zone where there is firn and refreezing, water rapidly penetrates to the bottom of the ice sheet yielding reduced basal traction and enhanced velocities. Our observations therefore support the short time scales of cryo-hydrologic warming (Philips et al., 2010). However, until now we have not observed a significant trend in the mean winter velocities in this region (Fig. 2) that mainly determine the annual velocities and the ice flux to the lower regions.

\section{Conclusions and outlook}

The data along the transect show a subtle pattern of response with respect to the position of the equilibrium line. In particular, in the higher ablation area annual velocities decrease near the equilibrium line. This suggests that the feedback between melt rates and velocity increases is of limited importance for decadal time scales. However, we observed a strong response near the equilibrium line in 2012. Hence further detailed suband englacial temperatures and water pressure measurements near and above the equilibrium line are needed to understand the importance of this observation.

It is, therefore, too early to conclude that melt rates are not important for the ice dynamics, as has been suggested (Tedstone et al., 2013; Shannon et al., 2013). However, we suggest a shift of research efforts from lubrication-enhanced flow in the ablation region towards water-penetrationinduced expansion of the sliding area, because this has much more potential to yield an acceleration of the annual ice flow.

\section{The Supplement related to this article is available online at doi:10.5194/tc-9-603-2015-supplement.}

Author contributions. R. S. W. van de Wal performed the interpretation and wrote the analysis together with C. J. P. P. Smeets. M. Stoffelen and R. van Kampen assisted with the data processing. All other co-authors contributed to the fieldwork and commented on the manuscript.

Acknowledgements. We thank P. Nienow, A. Sole and two anonymous reviewers for their constructive comments. The Netherlands Organisation for Scientific Research (NWO) and Netherlands Polar Program (NPP) funded this project. Additional funding was obtained via the Academy of Sciences (KNAW) and Utrecht University. We acknowledge the ice2sea project, funded by the European Commission's 7th Framework Programme through grant no. 226375. This research is part of ice2sea work package 2.2 and dedicated to the basal lubrication by surface melt. S. H. Doyle was supported by an Aberystwyth University doctoral scholarship. S. Lhermitte (KNMI) provided the background MODIS figure. Author Information: the authors declare no competing financial 
interests. Correspondence and requests for materials should be addressed to R. S. W. van de Wal (r.s.w.vandewal@uu.nl).

Edited by: E. Larour

\section{References}

Andreas, E. L.: A theory for scalar roughness and the scalar coefficients over snow and ice, Bound.-Lay. Meteorol., 38, 159-184, 1987.

Bartholomaus, T. C., Anderson, R. S., and Anderson, S. P.: Response of glacier basal motion to transient water storage, Nat. Geosci., 1, 33-37, 2008.

Bartholomew, I., Nienow, P., Mair, D., Hubbard, A., King, M. A., and Sole, A.: Seasonal evolution of subglacial drainage and acceleration in a Greenland outlet glacier, Nat. Geosci., 3, 408-411, 2010.

Bartholomew, I., Nienow, P., Sole, A., Mair, D., Cowton, T., King, M. A., and Palmer, S.: Seasonal variations in Greenland Ice Sheet motion: Inland extent and behaviour at higher elevations, Earth Planet. Sci. Lett. 307, 271-278, 2011.

Bartholomew, I., Nienow, P., Sole, a., Mair, D., Cowton, T., King, M. A.: Short-term variability in Greenland Ice Sheet motion forced by time-varying meltwater drainage: implications for the relationship between subglacial drainage system behaviour and ice velocity, J. Geophys. Res., 117, F03002, doi:10.1029/2011JF002220, 2012.

Chandler, D. M., Wadham, J. K., Lis, G. P., Cowton, T., Sole, A., Bartholomew, I., Telling, J., Nienow, P., Bagshaw, E. B., Mair, D., Vinen, S. and Hubbard, A.: Evolution of the subglacial drainage system beneath the Greenland ice sheet revealed by tracers, Nat. Geosci., 6, 195-198, 2013.

Colgan, W., Rajaram, H., Anderson, R. S., Steffen, K., Phillips, T., Joughin, I., Zwally, H. J., and Abdalati, W.: The annual glaciohydrology cycle in the ablation zone of the Greenland Ice Sheet: Part 1 Hydrology, J. Glaciol., 57, 697-709, 2011.

Colgan, W., Rajaram, H., Anderson, R. S., Zwally, H. J., Steffen, K., Phillips, T., and Abdalati, W.: The annual glaciohydrology cycle in the ablation zone of the Greenland Ice Sheet: Part 2 Observed and modeled ice flow, J. Glaciol., 58, 51-64, 2012.

Cowton, T., Nienow, P., Sole, A., Wadham, J., Lis, G., Bartholomew, I., Mair, D., and Chandler, D.: Evolution of drainage system morphology at a land-terminating Greenlandic outlet glacier, J. Geophys. Res.-Earth, 118, 1-13, 2013.

Das, S. B., Joughin, I., Behn, M. D., Howat, I.M., King, M. A., Lizarralde, D., and Bhatia, M. P.: Fracture propagation to the base of the Greenland ice sheet during supraglacial lake drainage, Science, 320, 778-781, 2008.

den Ouden, M. A. G., Reijmer, C. H., Pohjola, V., van de Wal, R. S. W., Oerlemans, J., and Boot, W.: Stand-alone single-frequency GPS ice velocity observations on Nordenskiöldbreen, Svalbard, The Cryosphere, 4, 593-604, doi:10.5194/tc-4-593-2010, 2010.

Dow, C. F., Hubbard, A., Booth, A. D., Doyle, S. H., Gusmeroli, A., and Kulessa, B.: Seismic evidence of mechanically-weak sediments underlying Russell Glacier, West Greenland. Ann. Glaciol., 54, 135-141, doi:10.3189/2013AoG64A032, 2013.

Doyle, S. H., Hubbard, A., Fitzpatrick, A. A. W., van As, D., Mikkelsen, A. B., Petterson R., Hubbard, B.: Persistent flow acceleration within the interior of the Greenland Ice Sheet, Geophys. Res. Lett., 41, 899-905, doi:10.1002/2013GL058933, 2014.

Fettweis, X.: Reconstruction of the 1979-2006 Greenland ice sheet surface mass balance using the regional climate model MAR, The Cryosphere, 1, 21-40, doi:10.5194/tc-1-21-2007, 2007.

Fitzpatrick, A. A. W., Hubbard, A. L., Joughin, I., Quincey, D. J., van As, D., Mikkelsen, A. P. B., and Doyle, S. H.: Ice flow dynamics and surface meltwater flux at the land-terminating margin of the west Greenland Ice Sheet, J Glaciol., 59, 687-696, doi:10.3189/2013JoG12J143, 2013.

Hoffman, M. J., Catania, G. A., Neuman, T. A., Andrews, L. C., and Rumrill, J. A.: Links between acceleration, melting, and supraglacial lake drainage of the western Greenland ice sheet, J. Geophys. Res., 116, F04035, doi:10.1029/2010JF001934, 2011.

Howat, I. M., Joughin, I., and Scambos, T. A.: Rapid changes in ice discharge from Greenland outlet glaciers, Science, 315, 15591561, 2007.

Howat, I. M., de la Peña, S., van Angelen, J. H., Lenaerts, J. T. M., and van den Broeke, M. R.: Brief Communication "Expansion of meltwater lakes on the Greenland Ice Sheet", The Cryosphere, 7, 201-204, doi:10.5194/tc-7-201-2013, 2013.

Iken, A. and Bindschadler, R.: Combined measurements of subglacial water pressure and surface velocity of Findelengletscher, Switzerland: conclusions about the drainage system and sliding mechanism, J. Glaciol., 32, 101-119, 1986.

Iken, A., Rothlisberger, H., Flotron, A., and Haeberli, W.: The uplift of Unteraargletscher at the beginning of the melt season - a consequence of water storage at the bed, J. Glaciol., 29, 28-47, 1983.

Iken, A., Echelmeyer, K., Harrison, W., and Funk, M.: Mechanisms of fast flow in Jakobshavns Isbræ, West Greenland, I: Measurements of temperature and water level in deep boreholes, J. Glaciol., International Glaciological Society, 39, 15-25, 1993.

Joughin, I., Das, S. B., King, M. A., Smith, B. E., Howat, I. M., and Moon, T.: Seasonal Speedup along the western flank of the Greenland Ice Sheet, Science, 320, 781-783, 2008.

Joughin, I., Das, S. B., Flowers, G. E., Behn, M. D., Alley, R. B., King, M. A., Smith, B. E., Bamber, J. L., van den Broeke, M. R., and van Angelen, J. H.: Influence of ice-sheet geometry and supraglacial lakes on seasonal ice-flow variability, The Cryosphere, 7, 1185-1192, doi:10.5194/tc-7-1185-2013, 2013.

Meierbachtol, T., Harper, J., and Humphrey, N.: Basal drainage system response to increasing surface melt on the Greenland ice sheet, Science, 341, 777-779, doi:10.1126/science.1235905, 2013.

Nghiem, S., Hall, D. K., Mote, T. L., Tedesco, M., Albert, M. R., Keegan, K., Shuman, C. A., DiGiolamo, N. E., and Neumann, G.: The extreme melt across the Greenland ice sheet in 2012, Geophys. Res. Lett., 39, L20502, doi:10.1029/2012GL053611, 2012.

Nick, F. M., Vieli, A., Andersen, M. L., Joughin, I., Payne, A., Edwards, T. L., Pattyn, F., and Van de Wal, R. S. W.: Future sealevel rise from Greenland's main outlet glaciers in a warming climate, Nature, 497, 235-237, 2013.

Palmer, S., Shepherd, A., Nienow, P., and Joughin, I.: Seasonal speedup of the Greenland Ice Sheet linked to routing of surface water, Earth Planet. Sci. Lett., 302, 3-4, 2011. 
Parizek, B. R.: Sliding to sea, Nat. Geosci., 3, 385-386, doi:10.1038/ngeo879, 2010.

Parizek, B. R. and Alley, R. B.: Implications of increased Greenland surface melt under global-warming scenarios: ice-sheet simulations, Quaternary Sci. Rev., 23, 1013-1027, 2004.

Philips, T., Rajaram, H., and Steffen, K.: Cryo-Hydrologic warming: a potential mechanism for rapid thermal response of ice sheets, Geophys. Res. Lett., 37, L20503, doi:10.1029/2010GL044397, 2010.

Price, S., Payne, A., Catania, G., and Neumann, T.: Seasonal acceleration of inland ice via longitudinal coupling to marginal ice, J. Glaciol., 54, 213-219, 2008.

Pritchard, H. D., Arthern, R., Vaughan, D., and Edwards, L. A.: Extensive dynamic thinning on the margins of the Greenland and Antarctic ice sheets, Nature, 461, 971-975, 2009.

Rignot, E. and Kanagaratnam, P.: Changes in the velocity structure of the Greenland ice sheet, Science, 311, 986-990, 2006.

Schoof, C.: Ice-sheet acceleration driven by melt supply variability, Nature, 468, 803-806, doi:10.1038/nature09618, 2010.

Shannon, S., Payne, A. J., Bartholomew, I. D., Van den Broeke, M. R., Edwards, T. L., Fettweis, X., Gagliardini, O., GilletChaulet, F., Goelzer, H., Hoffman, M. J., Huybrechts, P., Mair, D. W. F., Nienow, P. W., Perego, M., Price, S. F., Smeets, C. J. P. P., Sole, A. J., Van de Wal, R. S. W., and Zwinger, T.: Enhanced basal lubrication and the contribution of the Greenland ice sheet to future sea level rise, P. Natl. A. Sci., 110, 1415614161, doi:10.1073/pnas.1212647110, 2013.

Shepherd, A., Hubbard, A., Nienow, P., King, M., McMIllan, M., and Joughin, I.: Greenland ice sheet motion coupled with daily melting in late summer, Geophys. Res. Lett., 36, L01501, doi:10.1029/2008GL035758, 2009.

Shepherd, A., Ivins, E. R., Geruo A., Barletta, V. R., Bentley, M. J., Bettadpur, S., Briggs, K. H., Bromwich, D. H. Forsberg, R., Galin, N., Horwath, M., Jacobs, S., Joughin, I., King, M. A., Lenaerts, J. T. M., Li, J., Ligtenberg, S. R. M., Luckman, A., Luthcke, S. B., McMillan, M., Meister, R., Milne, G., Mouginot, J., Muir, A., Nicolas, J. P., Paden, J. Payne, A. J., Pritchard, H., Rignot, E., Rott, H., Sandberg Sørensen, L., Scambos, T. A., Scheuchl, B., Schrama, E. J. O., Smith, B., Sundal, A. V., Van Angelen, J. H., Van de Berg, W. J., Van den Broeke, M. R., Vaughan, D. G.,Velicogna, I., Wahr, J., Whitehouse, P. L.,Wingham, D. J., Yi,D., Young, D., Zwally, H. J.: A reconciled estimate of ice-sheet mass balance, Science, 338, 1183-1189, 2012.
Smeets, C. J. P. P. and Van den Broeke, M. R.: Temporal and spatial variation of momentum roughness length in the ablation zone of the Greenland ice sheet, Bound.-Lay. Meteorol., 128, 315-338, 2008a.

Smeets, C. J. P. P. and Van den Broeke, M. R.: The parameterisation of scalar transfer over rough ice surfaces, Bound.-Lay. Meteorol., 128, 339-335, 2008b.

Smeets, C. J. P. P., Boot, W., Hubbard, A., Petterson, R., Wilhelms, F., Van den Broeke, M. R., and Van de Wal, R. S. W.: A wireless subglacial probe for deep ice applications, J. Glaciol., 58, 211, 841-848, 2012.

Sole, A., Nienow, P., Bartholomew, I., Mair, D., Cowton, T., Tedstone, A., and King, M. A.: Winter motion mediates dynamic response of the Greenland Ice Sheet to warmer summers, Geophys. Res. Lett., 40, 3940-3944, doi:10.1002/grl.50764, 2013.

Sundal, A. V., Shepherd, A., Nienow, P., Hanna, E., Palmer, S., Huybrechts, P.: Melt-induced speed-up of Greenland ice sheet offset by efficient subglacial drainage, Nature, 469, 521-524, 2011.

Tedstone, A. J., Nienow, P. W., Sole, A. J., Mair, D. W. F., Cowton, T. R., Bartholomew, I. D., and King, M. A.: Greenland ice motion insensitive to exceptional meltwater forcing, P. Natl. A. Sci., 110, 19719-19724, doi:10.1073/pnas.1315843110, 2013.

van den Broeke, M., Smeets, P., Ettema, J., van der Veen, C., van de Wal, R., and Oerlemans, J.: Partitioning of melt energy and meltwater fluxes in the ablation zone of the west Greenland ice sheet, The Cryosphere, 2, 179-189, doi:10.5194/tc-2-179-2008, 2008.

Truffer, M., Harrison, W. D., and March, R.S.: Correspondence, Journal of Glaciology, 51, 663-664, 2005.

Van den Broeke, M. R., Bamber, J., Ettema, J., Rignot, E., Schrama, E., Van de Berg, W. J., Meijgaard, E., Velicogna, I., and Wouters, B.: Partitioning recent Greenland mass loss, Science, 326, 984 986, 2009.

Van de Wal, R. S. W., Boot, W., Van den Broeke, M. R., Smeets, C. J. P. P., Reijmer, C. H., Donkers, J. J. A., and Oerlemans, J.: Large and rapid melt-induced velocity changes in the ablation zone of the Greenland Ice Sheet, Science, 321, 111-113, 2008.

Van de Wal, R. S. W., Boot, Smeets, C. J. P. P., W., Snellen, H., Van den Broeke, M. R., and Oerlemans, J.: Twenty-one years of mass balance observations along the-K-transect, West Greenland, Earth Syst. Sci. Data, 4, 31-35, 2012, http://www.earth-syst-sci-data.net/4/31/2012/.

Zwally, H. J., Abdalati, W., Herring, T., Larson, K., Saba, J., and Steffen, K.: Surface melt-induced acceleration of Greenland IceSheet flow, Science, 297, 218-222, 2002. 